\title{
SOFTENING TREATMENT ON SISAL FIBRE USING ENZYMES
}

\author{
SHIRESHA MANYAM ${ }^{1} \&$ PADMA ALAPATI ${ }^{2}$ \\ ${ }^{I}$ Research Scholar, PJTSAU, Department. of Apparel \& Textiles, College of Home Science, PJTSAU, \\ Hyderabad, Telangana, India \\ ${ }^{2}$ Principal Scientist, AICRP-Home Science (Clothing \& Textiles), PG \& RC, PJTSAU, Hyderabad, Telangana, India
}

\begin{abstract}
The growing concerns for the degrading environmental conditions have led to the development of eco-friendly and biodegradable fibers in the ever expanding horizon of textile fibers. These fibers, being environmentally friendly, do not pose the toxic and waste disposal problems that are associated with some of the synthetic and mineral fibers. Because of these performance properties, eco-friendly fibers can be incorporated as a whole or part of materials and products of various forms for a wide range of applications. One such eco-friendly fibre is the sisal fibre, which has high potential as a textile fibre. Softening treatment was carried out on sisal fibre, in order to impart the smooth feel, lusture and handle of the fibre. Three Popular varieties of sisal in Andhra Pradesh were considered for the study, extracted fibre and enzyme treatment was given with four concentrations. Among all the fibers varieties, Agave Webert variety was found to have better physical characteristics before and after pretreatment.

KEYWORDS: growing concerns, eco-friendly fibers. \& better physical characteristics
\end{abstract}

Received: Sep 19, 2017; Accepted: Oct 07, 2017; Published: Oct 28, 2017; Paper Id.: IJASRDEC201717

\section{INTRODUCTION}

The present Scenario is all about increasingly environment conscious and natural clothing lifestyles are advancing. The inclination towards eco-friendly textile alternatives and the emergence of innovative fabrics is vivid. Now a day's, rising concern is health, sustainability of waste management and environmental awareness, which is reflecting on renewed interest in plant fibers. In the worldwide population and the concern of environmental friendliness, it is important to promote the recycling of resources and to strength efforts to save energy and resources. One approach is to develop new environmental- friendly fibre materials, such as wood-based biomass, starch, bio-degradable polyester, etc. and another approach is, to utilize the naturally existing fibers which are unconventional, in terms of non-availability fibers now familiar. Such non conventional fibres are currently used for various applications. Some non-conventional fibres are pineapple, banana, ramie, bamboo, milkweed and kenaf. Among all the non-conventional fibres Sisal is now ready, to join the marks of those most valuable varieties plant kingdom.

The use of enzymes in textile wet processing was well taken due to safety, energy, water conservation and environmental responsibility that make its use more prevalent. Hence, enzyme treatment for Sisal fibre was considered to improve its pliability. Accordingly, softening treatment was carried out on sisal fibre, in order to impart the smooth feel, lusture and pliability required, for better weavers knotting. 


\section{MATERIALS AND METHODS}

\section{Selection of Fibre}

The available varieties of sisal in Andhra pradesh namely Agave webert, Agave cantala, Agave Veracruz were considered for study, enzyme treatment was conducted, in order to assess the strength of the sisal varieties by tensile strength tester in the Department of Apparel and Textiles, College of Home Science, Saifabad, Hyderabad. Based on the observation of the tested fibre varieties for strength, Agave webert variety was selected for the study.

Agave webert fibre utilized for the study was extracted at Regional Agricultural Research Station (RARS) Chintapalli, Vizianagaram district, Andhra Pradesh.

As sisal is a very stiff fibre, and in order to soften the fibre, enzyme treatments was given to the selected fibre.

\section{Selection of Enzyme}

Enzymes are biocatalysts without which no life in plant or animal kingdom can be sustained. Enzymes are protein complex molecules and the Cellulases are multi component. These enzymes were extensively used in textiles finishing, to improve the hand of fabrics. Three laboratory grade cellulose enzymes, such as Sibasof, Microsil and New smooth (Britacel Limited, Mumbai) were selected for study. The description of each enzyme is given below.

\section{Sibosof Enzyme}

Sibasof is a reactive epoxy, silicone elastomeric offering remarkable bounciness to all kinds of fabrics and dress materials. It is nonionic in nature and milky white in appearance.

\section{Microsil Enzyme}

Microsil is a specially formulated micro amino silicone which when applied on fabrics gives it a good internal softness along with excellent surface smoothness. It is nonionic in nature and hazy to clear liquid in appearance.

\section{New Smooth Enzyme}

New smooth is an easily dispersible cold water soluble quarternised silicone cationic softener, with remarkable smoothness on all types of knits, hosiery and woven fabrics etc. It is nonionic in nature and creamish yellow in appearance

\section{EXPERIMENTAL PROCEDURE}

\section{Optimization of Enzyme Concentration}

To standardize the softening treatments on sisal fibre, three varieties of enzymes, namely Microsil, Sibosof and New smooth with four different concentrations of 0.5 percent, 1 percent, 1.5 percent and 2 percent were selected for each enzyme, based on the minimum recommended levels of enzyme concentration, by the manufacturing company, Britacel, Mumbai. 100 grams of fibre from the finest selected variety was weighed and used for enzyme treatment. Based on the weight of fibre, the enzyme requirement was calculated for providing concentration of 0.5 percent, 1 percent, 1.5 percent, and 2 percent. The M: L ratio of 1:30 was maintained. The recommended $\mathrm{pH} 5$, for the application of each enzyme was maintained. Fibre was placed in the solution, under continuous rotation for 30 minutes. Later, it was rinsed, dried in shade condition and subjected to tensile performance. 


\section{Assessment of Physical Properties of Enzyme Treated Sisal Fibre}

The enzyme treated sisal fibres were subjected to physical testing, to determine the quality parameters, which play a major role in the evaluation of the quality of the fabric.

\section{Fibre Tenacity (g/tex) and Elongation (\%)}

The maximum load (force) suggested by specimen in a tensile test, carried out to rupture is the breaking load or the tensile strength of the fibre. The breaking strength of the fibre determined, is usually taken as an index of fibre quality and is expressed either in grams or pounds. The specimens of $10 \mathrm{~cm}$ length were tested with the speed of $100 \mathrm{~mm} / \mathrm{min}$, $100 \mathrm{~mm}$ gauge length and with $10 \mathrm{kgs}$ specific load range under standard atmospheric conditions in DAK systems tensile testing machine in College of Home Science, Hyderabad.

The value of reading for elongation at break was simultaneously recorded and expressed in terms of percentage. Based on the quality parameters like strength, elongation at break, peak load and smoothness of the treated fibre, one best concentration should be selected from each enzyme.

\section{Enzyme Treatment on Fibre}

The standardization of softening treatments on sisal fiber was carried out with different enzyme concentrations and the enzyme treated sisal fiber was subjected to tensile strength testing. Based on the tensile performance of the fibre, the three enzymes, new smooth, Microsil and Sibas of were used in 2, 1.5, 1 and 0.5 percent, respectively. To optimize the enzyme treatment process, parameters such as temperature, $\mathrm{pH}$, time and $\mathrm{M}$ : $\mathrm{L}$ ratios were maintained, as shown in table 1

\section{Table 1: Parameters and Operational Ranges of Enzymes}

\begin{tabular}{|l|l|}
\hline \multicolumn{1}{|c|}{ Parameters } & \multicolumn{1}{c|}{ Operational Range } \\
\hline Temperature & Room temperature \\
\hline $\mathrm{pH}$ & 5 \\
\hline Time & 30 minutes \\
\hline Concentration & $\begin{array}{l}\text { New smooth-1.5\%, Microsil-1.5\%, } \\
\text { Sibasof- } 0.5 \%\end{array}$ \\
\hline M: L ratio & $1: 30$ \\
\hline
\end{tabular}

Enzyme treatment was carried out in a specially designed container; the fibre was steeped in water with M: L of 1:30 ratio and the $\mathrm{pH}$ was maintained at 5 . The enzyme was added as required, to the prepared liquor and the fibre was left in the solution for $30 \mathrm{~min}$. Then the fibre was rinsed and dried, as shown in figure $1 \& 2$ the fibre, thus finished was twisted manually.

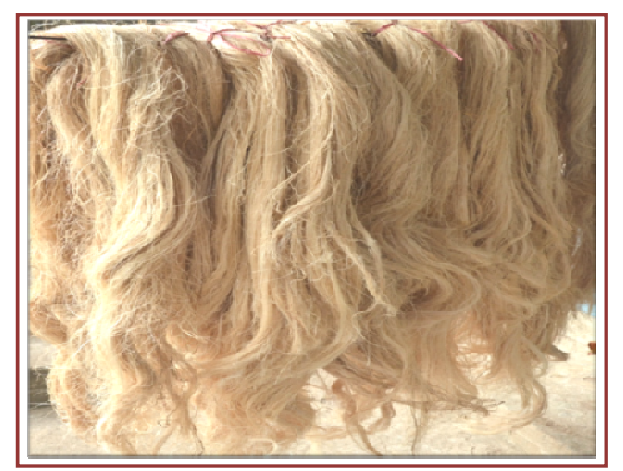

Figure 1: Enzyme Treated Sisal Fibre Agave webert 


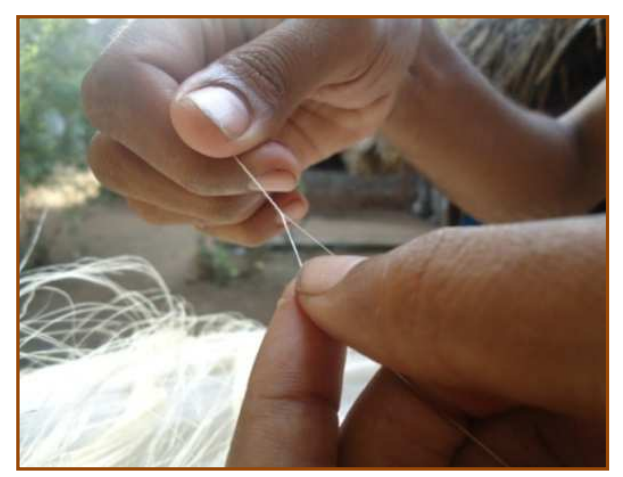

Figure 2: Weavers Twisting of Sisal Fibre

\section{RESULTS}

\section{Selection of the Fibre Variety}

The enzyme treatment was carried out on three varities of sisal fibre, with four different percentages of $0.5 \%, 1 \%$, $1.5 \%$ and $2 \%$ enzyme concentration. Three cellulase enzymes were selected for the enzyme treatment. Among all the enzymes, new smooth was selected based on subjective evaluation and objective evaluation and concentration. The tensile properties of the fibres were furnished in Table 2.

Table 2: Physical Properties of the Five Varieties of the Sisal Fibre

\begin{tabular}{|c|c|c|c|c|c|c|}
\hline $\begin{array}{c}\text { Name of the } \\
\text { variety }\end{array}$ & Sample & Enzyme & Enzyme (\%) & $\begin{array}{c}\text { Load } \\
\text { (Newton) }\end{array}$ & $\begin{array}{c}\text { Elongation } \\
(\%)\end{array}$ & Tenacity \\
\hline Agave webert & Control & - & - & 498 & 53.16 & 131.21 \\
\hline Agave webert & Treated & \multirow{4}{*}{$\begin{array}{l}\text { New } \\
\text { Smooth }\end{array}$} & $0.5 \%$ & 4.08 & 5.77 & 1.20 \\
\hline Agave webert & Treated & & $1 \%$ & 5.68 & 12.10 & 1.67 \\
\hline Agave webert & Treated & & $1.5 \%$ & 0.30 & 0.45 & 8.84 \\
\hline Agave webert & Treated & & $2 \%$ & 9.58 & 8.93 & 2.81 \\
\hline Agave cantala & Control & - & - & 408.9 & 81.89 & 107.62 \\
\hline Agave cantala & Treated & \multirow{4}{*}{ Microsil } & $0.5 \%$ & 8.27 & 4.60 & 2.43 \\
\hline Agave cantala & Treated & & $1 \%$ & 5.28 & 8.76 & 1.55 \\
\hline Agave cantala & Treated & & $1.5 \%$ & 8.91 & 6.60 & 2.62 \\
\hline Agave cantala & Treated & & $2 \%$ & 6.24 & 4.42 & 1.83 \\
\hline AgaveVeracruz & Control & - & - & 498.1 & 53.16 & 131.2 \\
\hline AgaveVeracruz & Treated & \multirow{4}{*}{ Sibasof } & $0.5 \%$ & 9.76 & 8.01 & 2.87 \\
\hline AgaveVeracruz & Treated & & $1 \%$ & 6.52 & 8.09 & 1.92 \\
\hline AgaveVeracruz & Treated & & $1.5 \%$ & 9.15 & 3.75 & 2.70 \\
\hline AgaveVeracruz & Treated & & $2 \%$ & 5.16 & 6.60 & 1.51 \\
\hline
\end{tabular}

Table 3: Physical Properties of the Agave Webert Sisal Fibre Compared with other fibres

\begin{tabular}{|l|l|c|c|c|}
\hline $\begin{array}{c}\text { Name of the fiber } \\
\text { variety }\end{array}$ & \multicolumn{1}{|c|}{ Sample } & $\begin{array}{c}\text { Load } \\
\text { (Newton) }\end{array}$ & Elongation (\%) & Tenacity \\
\hline Agave webert & Treated & 0.30 & 0.45 & 8.84 \\
\hline Agave cantala & Treated & 8.91 & 6.60 & 2.62 \\
\hline AgaveVeracruz & Treated & 9.76 & 8.01 & 2.87 \\
\hline
\end{tabular}

From the above table it was observed that, among all three varieties Agave Weber was observed with fine load, elongation, and tenacity hence this variety was selected for the study. 


\section{Tenacity of the Fibres}
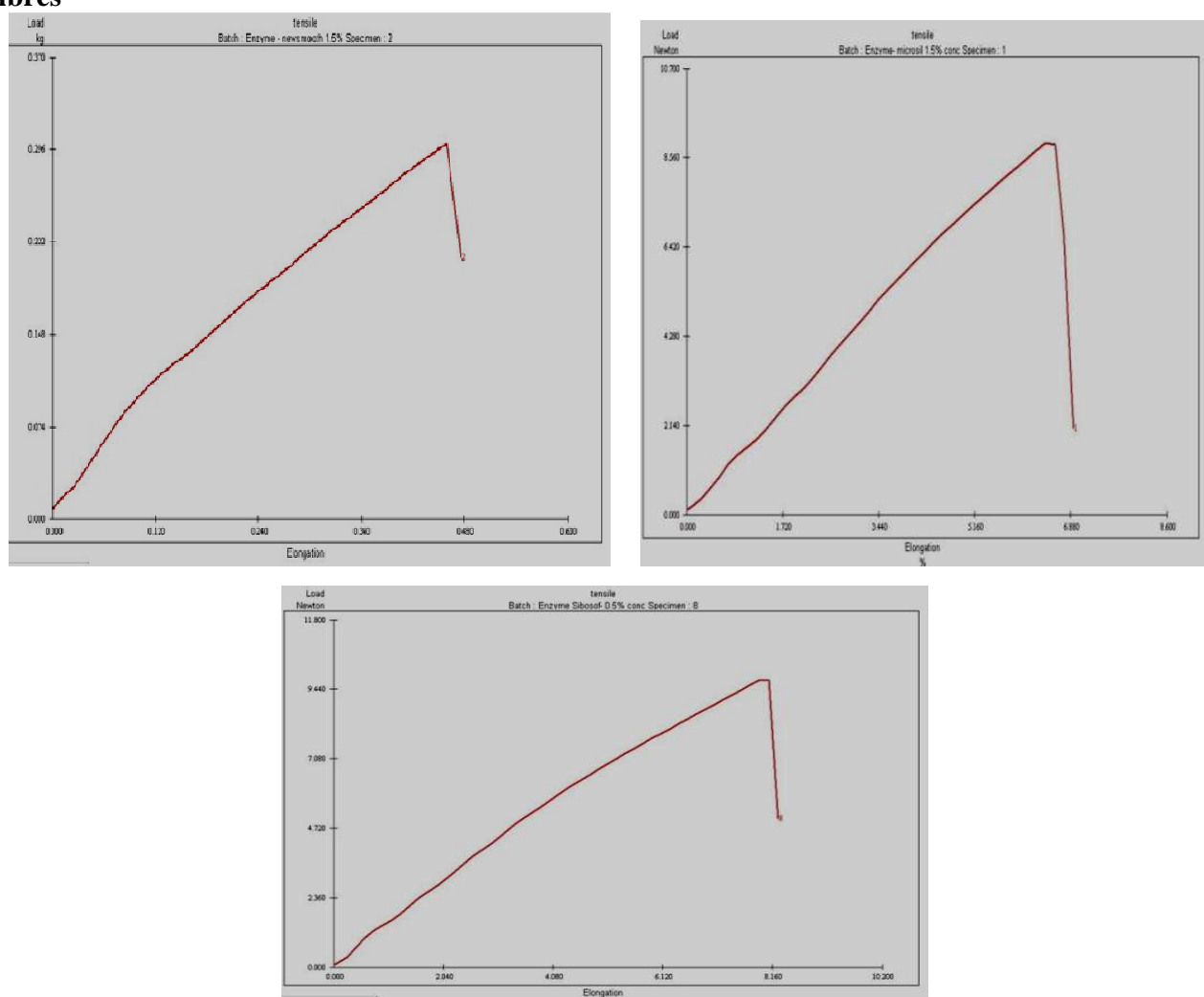

The above graphs revealed that among all the fibre varities Agave Webert with new smooth enzyme at $1.5 \%$ concentration, showed good tenacity with load and elongation, followed by Agave Cantala and Agave Veracruz varities. Among the three varieties, Agave Veracruz has shown very less tenacity of 2.26, when compared with the other varieties

\section{CONCLUSIONS}

Among all the fibre varieties, Agave Weber variety was found to have better physical characteristics, compared to other fibers. The tensile properties of Agave Webert variety showed good results, when compared with other varieties. From three varieties Agave Webert was observed with fine load, elongation, and tenacity hence, this variety was selected for the study.

\section{REFERENCES}

1. Ambrose, D. C. P., 2009. Corrugated fibre board boxes from sisal (Agave Sisalana)-an alternative to wooden packages. International journal of agricultural sciences, vol 50: 129-133.

2. Ammayappan, L and Gupta, N. P. 2011. Study on enzymatic assisted coloring of cotton fabrics, is focused to examine the performance of enzyme and its coloring ability using reactive dyes. Man made textiles, vol. 39. No. 7, 244-247.

3. Ammayappan, L., Jeyakodi, M., Raja. A. S. M. Pitchai, K. 2010. Effect of silicone and urethane finishing treatment on performance properties of enzyme treated wool/cotton union fabric. Manmade Textiles in India 47-50

4. Chand, N., Sood, S., Singh, D. K and Rohatgi, P. K. 1987. Structural and thermal studies on sisal fibre. Journal of Thermal Analysis. 32: 595-599.

5. Chattopadhyaya, D. P., Chattarjee, K. N., Bhandra, I. and Ruceere gember, 1997. Studies on enzymatic fading. Man-made Textiles in India, 40(1): 452-454. 
